Catherine Merridale. Night of Stone: Death and Memory in Twentieth-Century Russia. New York and London: Viking Penguin Books, 2002. 403pp. Notes, bibliography, index. Paperback. \$16.00. ISBN 0142000639.

For the best part of two years, from 1996 to 1998, the historian Cathy Merridale travelled around Russia and parts of the former Soviet Union in the company of her Russian research assistant, an ethnographer. Her aim was a study of mentalité, in this case death à la russe. Basing her work on the oral testimony of survivors (including families of victims), together with memoirs and other written sources, she was looking at the ways the terrible bloodshed, the fifty million lives lost from war, violence, famine and disease between 1914 and 1953, have affected the lives and aspirations of ordinary Russians. Night of Stone is the result. Oral history and folklore study have a good deal in common, especially when the testimony comes from those close to the traditional worldview, and the book does indeed have much to offer the folklorist. Part of this stems from the author's realization that, to understand the specificity of the Russian reaction to the tragedies of their recent history, she needed to be aware of the cultural context, in particular folk funeral rituals and death beliefs. Death rites, it is generally agreed, are more resistant to change than other life-cycle or calendar rituals. Without her ethnographer assistant by her side to provide information and sources, it seems probable that Night of Stone would have been another book by a historian, paying lip service to traditional oral culture with a paragraph or so based on a book or couple of articles. Here, by contrast, one of the strands running through the book details the ways in which traditional death beliefs maintained their hold over the population in various ways throughout the Soviet period and do so still today.

The book begins by presenting the cultural context: the practices laid down by the Orthodox Church, the state funeral of Alexander III, and then, mirabile dictu, a whole seventeen pages devoted to folk belief about funerals, death and the afterlife (pp. 29-46). Chapter II examines the reasons for Russia's high mortality rates, trying to escape the mythologizing constructs of Russian intellectuals or the deprecating attitudes of some Western commentators. Among the many factors (epidemics, famine, binge drinking, poverty, the low value placed by officialdom on human life, repressive policies, urbanization and so on), traditional peasant attitudes to disease and healing, it is suggested, also played their part. Chapter III looks at the evolution of the secular revolutionary funeral in the decades up to the Revolution. Chapter IV focuses on death and privation in the Civil War period, when essentially people reacted in three different ways: by experiencing trauma, by participating in the new collectivism, or, in the countryside, gaining solace as they always had done from religious rituals and beliefs. It took about ten years for an official substitute cult of the dead (with hagiographic overtones) to begin to emerge, notably in the funeral of Lenin, which is described in chapter V. This chapter also examines the attack on religion: the opening of saints' coffins, the closure of churches especially in the late twenties, the obliteration of cemeteries, and the attempts to bring in cremation and a Soviet-style funeral. For the folklorist what is particularly interesting is that in the 1920s cremation was not to be for those with families, but for outcasts and the homeless; exactly those who, it was traditionally believed, did not deserve a proper burial, and might only be remembered at Semik. 
The pages that follow in chapters VI and VII depict the grim horrors of collectivization and the Terror. While the show trials and deaths of 1937-41 cut swathes through the ranks of Party members, officials, intellectuals and Jews, collectivization had a devastating impact on the rural population, killing five to seven million people including whole communities especially in Ukraine. Memory, so important in Russian traditions about the dead, has in this instance largely evaporated, either because of psychological coping mechanisms, official lies, or the wholesale deaths of those who experienced the famine of 1933. During both of these terrible events one part of the population coped by closing its eyes and ears to what was happening to others. It may well be, though Merridale does not remark on this, that the division of people in the traditional worldview into "one's own" and "others" made this stance psychologically easier. By contrast, wilful ignorance was impossible during the war of 1941-45. Perhaps twenty five million people from all sectors of the population died, eight to ten million of them on the battlefield. Everyone was affected and involved in some way, and everyone had to cope. As many have noted, the presence of an external enemy united the country and helped the civilian population to endure hideous privation. Solidarity and endurance are a traditional response within the peasant worldview, with its emphasis on external hostile forces on the one hand and mutual community action in the face of them on the other.

Chapters IX, X and XI deal with the post-war Soviet period. Particularly interesting is the way in which Stalin chose to play down commemoration, because he feared a resurgence of religious belief in the wake of a general mood combining thanksgiving for victory and mourning for the dead. As a substitute, the population was exhorted to believe in the socialist utopian future and focus on heroism rather than personal mourning. For many this strategy worked. Socialist propaganda was stepped up, and in 1949 even the folktale was submitted to scrutiny by a committee determined to weed out its "backward" features (p. 250). As the following chapter notes, the post-Stalinist Thaw period witnessed attempts to escape the stultifying socialist rhetoric about the present and future and perhaps seek answers in religious belief. The official response, as far as death was concerned, was to redouble efforts to promote socialist funerary rituals, and make another (failed) attempt to institute cremation. Though the habit of silence had been partially broken, the tradition died hard, as veterans and families of the dead from the Afghan war realized as their attempts to talk about and deal with the realities were stamped on. It was only with the advent of glasnost that the tide of bones, as Chapter XI so eloquently puts it, of those who had died untimely deaths and whose memory had been obliterated finally surged into public view. The folkloric parallels and inversions are evident. These millions of people resembled the traditional "restless dead," in that they too had been in limbo, unable to pass into tot svet. They were, however, not restless, but in the darkness of oblivion where they could not be commemorated openly. Not restless but not resting either. With greater openness in Russian society their memory could finally be commemorated and their bones laid to rest.

The concluding chapter pulls together many of the points of discussion, notably rejecting the myth of Russian culture as barbaric, as well as underlining the significance of the Russian rejection of victimhood. In so doing the author casts doubt on the universal validity of the concept of post-traumatic stress syndrome. The chapter also considers the question of continuities in Russian funerary tradition. While one must applaud the 
accuracy and detail of the information about traditional rites, as well as the recognition of the importance of burial in native soil and commemoration of the family dead, as far as the folklorist is concerned, Merridale still occasionally underplays the striking continuities in basic attitudes to death. The reason may well be connected with her ethnographer informants. In the introduction she notes that in Russian funerary ritual "there is little that has not been altered, superficially at least, even the meaning of the dead" (p. 8). The evidence of the book strongly contradicts this statement, unless the emphasis is placed very heavily on the "superficially at least," and by the end the author herself feels impelled to express her scepticism about the standard view in Russian ethnography that by the late 1960s Soviet policies had destroyed tradition (p. 339). A brief conversation with a Western folklorist would have cleared up the mystery, and allowed her to be more confident in her assertions. The prime concern of Russian folklorists and ethnographers is nostalgic; they aim to capture an ancient, disappearing rural culture, and there is no doubt that, compared with the elaborate traditional funeral rites and beliefs collected before the Revolution, much has disappeared. Western folklorists, on the other hand, are interested in continuities and change as well, and would agree that the key attitudes and beliefs relating to death still persist. They might also have presented folk beliefs about death by starting from the basic concepts in the traditional worldview rather than from everyday rural life. Understanding, for example, the ramifications of svoi (one's own) and chuzhoi (others'), mentioned here in passing, sheds light on death, on the way to live, on concepts of the earth, attitudes to outsiders, foreigners and so on. The author would have found reading some of the work of the Moscow ethno-linguists helpful here, but it looks as though she was linked to the ethnographic traditions of the Institute of Anthropology and Ethnography. Typically in Russia each major institute tends to focus on its own approach to the subject. A folklorist might also have further pursued the cultural underpinnings of the Russian acceptance of suffering, and rejection of victimhood, as well as the significance of story telling in Russian culture. There is also one error, unfortunately highlighted by being used as a chapter title. In this book tot svet is wrongly translated as "another light" (with "pale light" presumably rendering belyi svet, "the world" (p. 123)). Though svet does mean "light," its other meaning, "world," is found in the very earliest Slavonic texts where the phrase onyi světŭ_means the world beyond the grave.

Many of the points above are questions of emphasis, and do little to diminish the value of the book for anyone with an interest in the way history and tradition have affected and continue to affect Russians. The tale is a profoundly tragic one. It is told without hysteria, but with compassion, frequent admiration and sorrow; Merridale is clearly aware that her own life will never be the same after the time she spent with people who had endured so much. At times it feels that her respect for their endurance and desire not to intrude too much into their painful memories and their psyches make her shy away from hard, possibly negative conclusions about her informants and their culture. She prefers to listen to the informant who asked her to try to make her readers understand. In this she succeeds.

\section{Faith Wigzell}

School of Slavonic and East European Studies, University College London 